\title{
Morphogenetic and structural characteristics of clones of elephant grass managed under intermittent stocking
}

\section{Características morfogênicas e estruturais de clones de capim- elefante anão manejados sob lotação intermitente}

\author{
Priscila Beligoli Fernandes ${ }^{1 *}$; Carlos Augusto Brandão de Carvalho'; \\ Domingos Sávio Campos Paciullo; ; Carlos Augusto de Miranda Gomide \\ Mirton José Frota Morenz ${ }^{3}$; Francisco José da Silva Lédo ${ }^{3}$
}

\begin{abstract}
This work was carried out to evaluate the morphogenetic and structural characteristics of basal and aerial tillers of two dwarf elephant grass clones (BRS Kurumi and CNPGL 00-1-3) managed under intermittent stocking in six grazing cycles. A completely randomized experimental design with three replications (paddocks) in split-split-plot arrangements was used. The clones were allocated to the plots, tiller classes were assigned to the subplots and grazing cycles to sub subplots. Higher values for basal tillers than aerial tillers were seen for the following characteristics: leaf elongation rate (12.8 and 5.1 $\mathrm{cm} /$ tiller/day), leaf appearance rate ( 0.26 and 0.19 leaves/tiller/day), stem elongation rate ( 0.38 and 0.16 $\mathrm{cm} /$ tiller/day), senescence rate $(0.98$ and $0.47 \mathrm{~cm} /$ tiller/day), total number of leaves ( 9.3 and 7.1 leaves/ tiller), number of live leaves (7.7 and 5.8 leaves/tiller) and final length of leaf blades (33.5 and 20.0 $\mathrm{cm})$. Phyllochron was lower for basal (4.0 days/leaf) than aerial tillers (5.5 days/leaf). The leaf life span increased with the advance of the grazing cycles, averaging 31.2 days. The tiller density increased with the advance of the grazing cycles showing an average increase of $167 \%$ of aerial tillers and $62 \%$ of basal tillers for both clones. The morphogenetic and structural characteristics of dwarf clones were influenced jointly by the clones and the availability of the environmental factors of growth during the spring and summer. The high leaf elongation rates, associated with high leaf appearance rate, reveal the potential of high production dry matter of leaves and restoration of leaf area after grazing.
\end{abstract}

Key words: Basal and aerial tillers. Morphogenesis. Pennisetum purpureum.

\section{Resumo}

Este trabalho objetivou avaliar características morfogênicas e estruturais de perfilhos basais e aéreos de dois clones (BRS KURUMI e CNPGL 00-1-3) de capim-elefante anão manejados sob lotação intermitente, durante seis ciclos de pastejo. Foi utilizado o delineamento experimental inteiramente casualizado em arranjo de parcelas sub-subdividas com três repetições, sendo os clones alocados às parcelas, as class de perfilhos às subparcelas e os ciclos de pastejo às subsubparcelas. Foram verificados maiores valores para perfilhos basais, quando comparados aos aéreos, para as seguintes características: taxa de alongamento foliar (12,8 e 5,1 cm/perfilho/dia), taxa de aparecimento foliar ( 0,26 e 0,19 folha/ perfilho.dia), taxa de alongamento de colmos $(0,38$ e $0,16 \mathrm{~cm} /$ perfilho.dia $)$, taxa de senescência $(0,98$

\footnotetext{
1 Discente, Curso de Doutorado em Zootecnia, Dept ${ }^{0}$ de Nutrição Animal e Pastagens, Universidade Federal Rural do Rio de Janeiro, UFRRJ, Seropédica, RJ, Brasil. E-mail: priscila.beligoli@hotmail.com

2 Prof., Instituto de Zootecnia, Dept ${ }^{0}$ de Nutrição Animal e Pastagens, UFRRJ, Seropédica, RJ, Brasil. E-mail: carloscarvalho_ ufrrj@yahoo.com.br

3 Pesquisadores, Empresa Brasileira de Pesquisa Agropecuária, EMBRAPA Gado de Leite, Juiz de Fora, MG, Brasil. E-mail: domingos.paciullo@embrapa.br; carlos.gomide@embrapa.br; mirton.morenz@embrapa.br; franscisco.ledo@embrapa.br Author for correspondence
} 
e $0,47 \mathrm{~cm} /$ perfilho.dia), número total de folhas ( 9,3 e 7,1 folhas/perfilho), número de folhas vivas $(7,7$ e 5,8 folhas/perfilho) e maior comprimento final da lâmina foliar $(33,5$ e 20,0 cm). O filocrono foi menor para os perfilhos basais (4,0 dias/folha) que para os aéreos (5,5 dias/folha). A longevidade da lâmina foliar aumentou com o avanço dos ciclos de pastejo, apresentando valor médio de 31,2 dias. Para perfilhos aéreos e basais houve um aumento na densidade populacional com o avanço dos ciclos de pastejo, apresentando um acréscimo médio de $167 \%$ dos perfilhos aéreos e de $62 \%$ dos perfilhos basais para ambos os clones. As características morfogênicas e estruturais dos clones anões foram influenciadas conjuntamente pelos clones e pela disponibilidade dos fatores ambientais de crescimento durante a primavera e o verão. As elevadas taxas de alongamento foliar, associadas à alta taxa de aparecimento foliar, revelam o elevado potencial de produção de massa seca de folhas, e de restauração da área foliar após o pastejo dos clones estudados.

Palavras-chave: Morfogênese. Pennisetum purpureum. Perfilhos aéreos e basais.

\section{Introduction}

Elephant grass (Pennisetum purpureum Schum.) has great production potential (PEREIRA; LÉDO, 2008). However, aside from being a highly seasonable forage species, the fast stem growth of the normal-size cultivars, the resulting handling difficulty and the need for frequent cropping, which adds to the cost of animal production, have contributed to make its adoption by producers difficult (PACIULLO et al., 2003; CARVALHO et al., 2006a).

The use of small-size cultivars that are better suited to grazing may make it easier to maintain proper forage canopy structure, as it affects the use and conversion of forage due to modifications in morphological composition and the quality of the forage provided to animals (CARVALHO et al., 2009). Seeking to make the handling of elephant grass easier, Embrapa Dairy Cattle Research Centre, in partnership with other research centers, selected to investigate two small-size clones of elephant grass (BRS KURUMI and CNPGL 00-1-3) that stand out for their high production potential and nutritional value. As the development of these clones is recent, detailed information on their growth characteristics under pasture is necessary as a reference for the adoption of appropriate management practices, since forage grass productivity results from the continued production of leaves and tillers, a process that is important for the restoration of leaf area under grazing conditions (GOMIDE; GOMIDE, 2000).
Morphogenetic studies on the growth dynamics of leaves and tillers of forage grasses have enabled the definition of grass management strategies under various environmental conditions (SILVA et al., 2008). The appearance and elongation of these structures enable the restoration of the leaf area of forages after grazing and contribute to the maintenance of forage production and pasture perennity (PACIULLO et al., 2003). Furthermore, morphogenetic investigation can also help accelerate the selection of materials in genetic improvement programs (VAN ESBROECK et al., 1997; RODRIGUES et al., 2011).

The objective of this study was to assess the morphogenetic and structural characteristics of basal and aerial tillers in pastures of two small-size clones of elephant grass managed under intermittent stocking for six grazing cycles during the spring and summer.

\section{Materials and Methods}

This study was conducted in the Experimental Field of Santa Mônica of Embrapa Dairy Cattle Research Centre, located in the municipality of Valença, Rio de Janeiro State, with an area of 6,300 $\mathrm{m}^{2}$ and cultivated with two clones of elephant grass. According to Köppen, the region is a Cwa climate type (mesothermal), with a rainy summer from November to February and a dry winter from June to September. The annual rain fall is $1,535 \mathrm{~mm}$; the average monthly rainfall in the dry season is around 
$20 \mathrm{~mm}$ and $253 \mathrm{~mm}$ in the months with the most rain (November to February), reaching $295 \mathrm{~mm}$ in December and January. Climate data were collected at the meteorological station of the Experimental Field, about 1,000 $\mathrm{m}$ away from the experimental area (Figure 1). Table 1 presents the rain distribution during the experimental period. The soil of the experimental area is classified as Regolytic Neosol (EMBRAPA, 2006). Chemical analysis of soil samples collected from 0-20 cm in September 2008 revealed the following chemical characteristics: $\mathrm{pH}$ in water of 5.7, dissoluble $\mathrm{P}\left(\mathrm{Mehlich}^{-1}\right)$ of $10.45 \mathrm{mg}$ $\mathrm{dm}^{-3}, \mathrm{H}+\mathrm{Al}$ of $3.4 \mathrm{cmol}_{\mathrm{c} \mathrm{dm}} \mathrm{d}^{-3}, \mathrm{~K}$ of $171 \mathrm{mg} \mathrm{dm}^{-3} ; \mathrm{Ca}$ of $2.7 \mathrm{cmol}_{\mathrm{c}} \mathrm{dm}^{-3}$, and $\mathrm{Mg}$ of $1.4 \mathrm{cmol}_{\mathrm{c}} \mathrm{dm}^{-3}$. During the experimental period, maintenance fertilization was performed in doses of $150 \mathrm{~kg} \mathrm{ha}^{-1}$ of $\mathrm{N}, 37.5 \mathrm{~kg}$ ha-1 of $\mathrm{P}_{2} \mathrm{O}_{5}$ and $150 \mathrm{~kg} \mathrm{ha}^{-1}$ of $\mathrm{K}_{2} \mathrm{O}$, applied in three equal fractions.

Figure 1. Precipitation and temperature maximum, minimum and mean registered during the trial period.

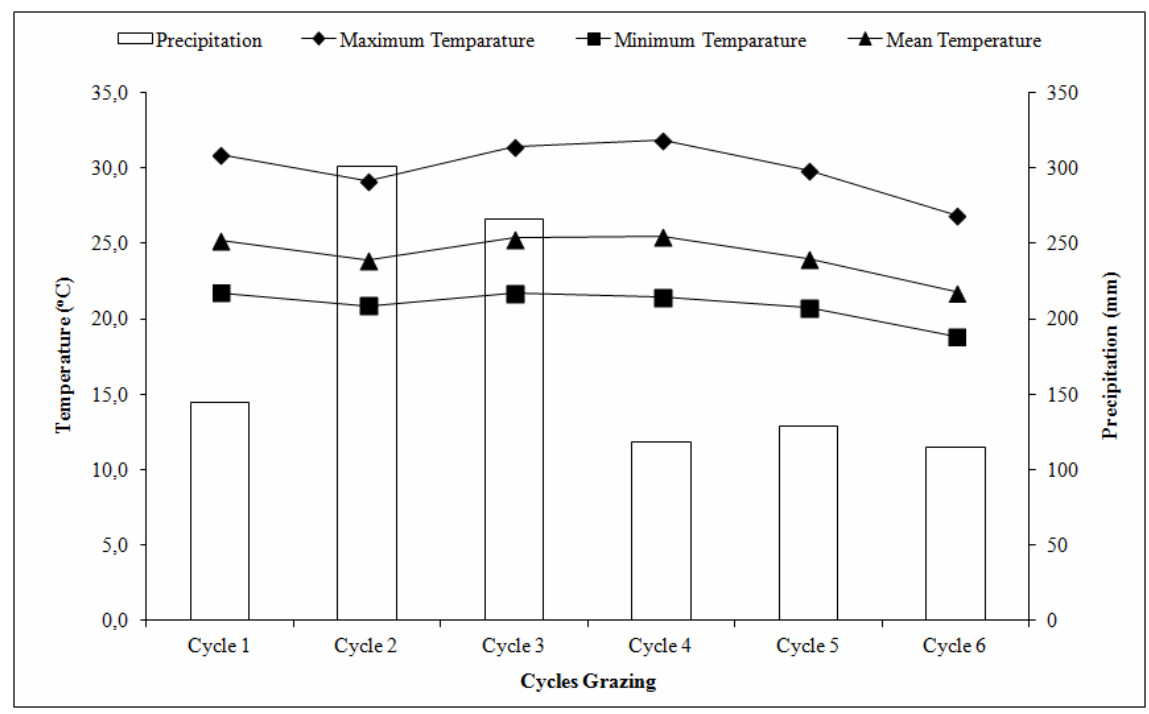

Table 1. Distribution of rainfall during the experimental period.

\begin{tabular}{lcccccc}
\hline $\begin{array}{c}\text { Grazing } \\
\text { Cycle }\end{array}$ & Period & $\begin{array}{c}\text { Duration } \\
\text { (days) }\end{array}$ & $\begin{array}{c}\text { Total rainfall } \\
\text { (mm) }\end{array}$ & $\begin{array}{c}\mathbf{N}^{\mathbf{0}} \text { days with } \\
\text { rainfall }\end{array}$ & $\begin{array}{c}\mathbf{N}^{\mathbf{0}} \text { days } \\
\text { without } \\
\text { rainfall }\end{array}$ & $\begin{array}{c}\mathbf{N}^{\mathbf{0}} \text { consecutive } \\
\text { days without } \\
\text { rainfall }\end{array}$ \\
\hline Cycle 1 & $05 / 11 / 09$ to $01 / 12 / 09$ & 27 & 144 & 13 & 14 & 4 \\
Cycle 2 & $01 / 12 / 09$ to 29/12/09 & 29 & 235 & 17 & 12 & 5 \\
Cycle 3 & $29 / 12 / 09$ to 22/01/10 & 25 & 268 & 9 & 16 & 12 \\
Cycle 4 & $22 / 01 / 10$ to $16 / 02 / 10$ & 26 & 114,6 & 4 & 22 & 15 \\
Cycle 5 & $16 / 02 / 10$ to $12 / 03 / 10$ & 25 & 205 & 16 & 9 & 4 \\
Cycle 6 & $12 / 03 / 10$ to $06 / 04 / 10$ & 26 & 127,4 & 9 & 17 & 9 \\
\hline
\end{tabular}

The area was divided into 14 paddocks measuring $900 \mathrm{~m}^{2}$ each, to which each of two treatments (two clones) were assigned, with seven paddocks each, managed under intermittent stocking with a defoliation interval of 24-days and four days of grazing by mixed-breed heifers (Dutch x Zebu).
Gomide et al. (2008) artificially conditioned (cropping) different sizes of clones before and after grazing and found the best forage performance for mean heights between 80 and $90 \mathrm{~cm}$ and residue heights between 30 and $35 \mathrm{~cm}$. Therefore, although the time in days mentioned above was adopted as 
an initial reference, the grazing management was based on before and after grazing heights proposed by Gomide et al. (2008).

The experiment was conducted from November 2009 to April 2010 and six grazing cycles were assessed (Cycle 1: Nov. 05 to Dec. 01, 2009, Cycle 2: Dec 01 to Dec. 29, 2009, Cycle 3: Dec. 29, 2009 to Jan. 22, 2010, Cycle 4: Jan. 22 to Feb. 16, 2010, Cycle 5: Feb. 16 to Mar. 12, 2010, and Cycle 6: Mar. 12 to Apr. 6, 2010).

A complete randomized block design with split plot arrangement with two plots, two subplots, six sub subplots, and three replications was adopted.

The treatment involved two elephant grass clones (BRS KURUMI and CNPGL 00-1-3) assigned to each of the plots. In the sub plots, tiller class types (aerial or basal) were assessed; in the sub subplots, grazing cycles ( including elongation and leaf appearance rates, phyllochron, stem elongation rates, senescence rates, leaf blade longevity, total number of leaves, number of live leaves, and final leaf length were assessed in the first four grazing cycles, according to Chapman and Lamaire (1993). Density of aerial and basal tillers was assessed in all six grazing cycles.

For the assessment of the morphogenetic variables, three representative plants were selected from each of the three plots. From each plant, one aerial and one basal tiller were selected and marked with a ribbon, totaling three aerial and three basal tillers per experimental unit and 18 tillers per clone (nine of each class). The assessment began three days after the removal of the animals from the plots (paddocks) and was performed at an average interval of seven days in the between defoliation interval, totaling three assessments per defoliation interval in each grazing cycle.

A millimeter ruler was used to measure the (a) green leaf blade length, from the ligule of the last elongated leaf, for elongating leaves and from the ligule of the measured leaf, for fully elongated or senescent leaves (DURU; DUCROCQ, 2000) and (b) stem length, from the plant crown insertion (basal) and the lateral tiller insertion in basal tillers (aerial) up to the ligule of the last elongated leaf (CARVALHO et al., 2005).

Using methods described by Bircham and Hodgson (1983) and Chapman and Lemaire (1993), these data were used to calculate: (a) the leaf elongation rate ( $\mathrm{cm} /$ tiller.day), as the quotient of the difference between the total final length of elongating leaves and the total initial length by the number of assessment days; (b) the stem elongation rate $(\mathrm{cm} /$ tiller.day), as the quotient of the difference of the total final stem length and the initial length and the number of assessment days; (c) the leaf senescence rate ( $\mathrm{cm} /$ tiller.day), as the quotient of the total final length of senescent tissue by the number of assessment days; (d) the leaf appearance rate (leaves/tiller.day), as the quotient of the total number of leaves that appeared on marked tillers and the number of assessment days; (e) phyllochron (days/leaf.tiller), as the inverse of the leaf appearance rate; (f) the total number of leaves (leaves/tiller), for the total number of live, green and senescent leaves/tiller; ( $g$ ) the number of live leaves (leaves/tiller), as the mean number of elongating and non-senescent elongated leaves per tiller in the assessment period; (h) the final leaf blade length (cm), as the mean leaf blade length of all elongated leaves on the tiller, senescent parts excluded; and (e) leaf blade longevity (days), as the number of live leaves per tiller, and phyllochron. To estimate the basal and aerial tiller population density, forage mass subsamples were counted before grazing.

The mean value of three sampling units per plot were analyzed to obtain the experimental unit values. Variance analysis of the non-transformed data was performed using the MIXED procedure of the $\mathrm{SAS}^{\circledR}$ statistical package (Statistical Analysis System, version 9.0), specific for measurements repeated over time and for which time is a factor to be investigated as a cause of variation. The variance and covariance matrixes were chosen using the Akaike Information Criterion (WOLFINGER, 
1993), and variance analysis was performed for variation causes: clones, tiller class, grazing cycles, and their interactions. The effects of clones, tiller class, grazing cycles and their interactions were considered as fixed. The experimental error between units and error for the same time unit were considered random effects. The treatment mean values were estimated using LSMEANS, and the values were compared using difference probability (PDIFF) at a probability level of 5\%.

\section{Results and Discussion}

Leaf elongation rates (LERs) were influenced by tiller class $(\mathrm{P}=0.0045)$ and grazing cycles $(\mathrm{P}=0.0354)$. Basal tillers had greater LERs (12.8 $\mathrm{cm} /$ tiller.day) than aerial tillers $(5.1 \mathrm{~cm} /$ tiller.day $)$.
These results corroborate those of Paciullo et al. (2003), who found greater LER values for basal than for aerial tillers of elephant grass cv. Napier ( 9.8 and $5.1 \mathrm{~cm} /$ tiller.day, respectively). The LERs decreased sharply in the fourth grazing cycle (Table 2), a period with reduced rainfall (Figure 1), demonstrating that, although the LER is genetically determined, climatic factors can significantly influence it (CHAPMAN; LEMAIRE, 1993). In the field, environment variables act simultaneously on grass growth, intensifying the effects of climate on the morphogenetic characteristics. Thus, the effects of drought may be associated with other factors, such as above-optimum temperature and reduced nutrient availability, which is normally found in limited hydric conditions (NABINGER; PONTES, 2001).

Table 2. Leaf elongation rate (cm/tiller.day) of clones of dwarf elephant grass during four grazing cycles.

\begin{tabular}{ccc}
\hline Grazing Cycle & Mean $^{(1)}$ & SEM $^{(2)}$ \\
\hline C1 (from 05/11/09 to 01/12/09) & $10.5^{\mathrm{A}}$ & 1.13 \\
C2 (from 01/12/09 to 29/12/09) & $7.7^{\mathrm{BC}}$ & 1.19 \\
C3 (from 29/12/09 to 22/01/10) & $10.3^{\mathrm{AB}}$ & 1.20 \\
C4 (from 22/01/10 to 16/02/10) & $7.4^{\mathrm{C}}$ & 0.13 \\
\hline
\end{tabular}

(1) Means in the same column followed by the same letter do not differ $(\mathrm{P}<0.05)$ by "t" test of "Student" ("PDIFF"). (2) Standard error of the mean.

Leaf appearance rates (LARs) were influenced by the interaction between grazing cycle and clone $(\mathrm{P}=0.0077)$ and by tiller class $(\mathrm{P}=0.0112)$. Basal tillers had greater LARs (0.26 leaf/tiller.day) than aerial tillers (0.19 leaf/tiller.day), which may have been due to a greater stem elongation rate of basal tillers during the experimental period. Due to the greater elongation of internodes, the new leaves may have been "pushed away" from the sheath of the previous leaf (CRUZ; BOVAL, 2000). Lower LAR values were found in the first, second and fourth cycles for the BRS KURUMI clone, and in the second and fourth cycles, for the CNPGL 001-3 clone, which made the interactions evident (Table 3 ). In the third grazing cycle, greater LAR values were observed for both clones. The mean LAR values (0.22 and 0.23 leaves/tiller.day for BRS KURUMI and CNPGL 00-1-3, respectively) indicate a high potential for leaf emission when compared to elephant grass cv. Mott (0.15 leaf/tiller. day), as reported by Almeida et al. (2000). As LARs are related to genotype (PINTO et al., 1994), level of insertion (SKINNER; NELSON, 1992), and environmental factors, such as light (LAWLOR, 1995), temperature (COLLINS; JONES, 1988), soil water and mineral nutrient contents (LAWLOR, 1995), season (VINE, 1983), and cropping intensity (DAVIES, 1974) LAR is a major morphogenetic characteristic of these new clones for leaf production. 
Table 3. Leaf appearance rate (leaves/tiller.day) of two clones of dwarf elephant grass during four grazing cycles.

\begin{tabular}{cccc}
\hline \multirow{2}{*}{ Grazing Cycle } & \multicolumn{2}{c}{ Dwarf elephant grass clones $^{(\mathbf{1})}$} & \multirow{2}{*}{ SEM $^{(2)}$} \\
\cline { 2 - 3 } & BRS KURUMI & CNPGL 00-1-3 $^{\mathrm{Aa}}$ & 0.01 \\
C1 (from 05/11/09 to 01/12/09) & $0.22^{\mathrm{Ba}}$ & $0.26^{\mathrm{Aa}}$ & 0.01 \\
C2 (from 01/12/09 to 29/12/09) & $0.23^{\mathrm{Ba}}$ & $0.20^{\mathrm{Ba}}$ & 0.01 \\
C3 (from 29/12/09 to 22/01/10) & $0.27^{\mathrm{Aa}}$ & $0.25^{\mathrm{Aa}}$ & 0.002 \\
C4 (from 22/01/10 to 16/02/10) & $0.16^{\mathrm{Cb}}$ & $0.21^{\mathrm{Ba}}$ & 0.05 ) \\
\hline
\end{tabular}

(1) Means followed by the same lowercase letter on the line and by the same capital letter in the column do not differ $(\mathrm{P}<0.05)$ by " $\mathrm{t}$ " test of "Student" ("PDIFF"). (2) Standard error of the mean.

Phyllochron was influenced by the interaction between the grazing cycle and clone $(\mathrm{P}=0.0099)$ and by tiller class $(\mathrm{P}=0.0064)$. Aerial tillers had high phyllochron values (5.5 days/leaf.tiller) in relation to basal tillers (4.0 days/leaf.tiller). This may have been due to the low pasture canopy height observed for the clones assessed (mean of $78 \mathrm{~cm}$ before grazing), which allowed a greater incidence of light at the canopy base and favored a lower leaf appearance interval on the basal tillers. These values are lower than those observed by Paciullo et al. (2003) for elephant grass cv. Napier (6.3 and 7.5 days/leaf for basal and aerial tillers, respectively). This low phyllochron reinforces the high leaf emission potential of the investigated elephant grass clones and their promising use in pasture, since phyllochron is an important variable for the production and perennity of the plant community in forage canopies (LEMAIRE; CHAPMAN, 1996). Regarding the pasture cycle effects, greater phyllochron values were found in the first and fourth cycles for the BRS KURUMI clone, and the second and fourth cycles for the CNPGL 00-13 clone (Table 4). In the third grazing cycle, lower phyllochron values were found for both clones. The shortest and longest leaf appearance times of the third and fourth grazing cycles, respectively, of both clones make it evident that these plants are not adapted to low rainfall regions, as these cycles had the greatest and lowest rainfall, respectively. The mean values found during the assessment period corroborate the values reported by Paciullo et al. (2003) for summer (4.9 leaves/day).

Stem elongation rates (SERs) were influenced by the interactions between the clone, tiller class and grazing cycle ( $\mathrm{P}=0.0418)$. Regarding tiller class, the BRS KURUMI clone had a greater value for basal tillers in the second and third grazing cycles ( 0.48 and $0.51 \mathrm{~cm} /$ tiller.day, respectively), while the CNPGL 00-1-3 clone had greater values for basal tiller in the second and fourth cycles $(0.55$ and $0.31 \mathrm{~cm} /$ tiller. day, respectively). Comparatively, basal tiller values were more similar in the first and second grazing cycles. In the third grazing cycle, greater values were observed for the BRS KURUMI clone ( 0.51 $\mathrm{cm} /$ tiller.day), while in the fourth grazing cycle, clone CNPGL 00-1-3 had a greater value $(0.31 \mathrm{~cm} /$ tiller.day) (Table 5). Aerial tillers of both clones had similar behaviors during the experimental period (Table 5). Regarding grazing cycles, the SER results suggest that BRS KURUMI tillers were cut from cycles three to four (Table 5). For clone CNPGL $00-1-3$, the results showed recovery from previous tiller cutting in the same period, which suggests good regeneration capacity for the CNPGL 00-1-3 clone, even under the adverse climate conditions of cycle four. It is necessary to point out that it is not possible to infer about the regeneration capacity of clone BRS KURUMI, as the fifth grazing cycle was not assessed. The variation of the behavior of this variable during the experimental period determined the occurrence of the observed interaction. The mean SER values of basal $(0.39 \mathrm{~cm} /$ tiller.day $)$ and aerial $(0.16 \mathrm{~cm} /$ tiller.day $)$ tillers were from three to five times smaller than those of the basal and aerial tillers of elephant grass cv. Napier (1.5 and 0.83 $\mathrm{cm} /$ tiller.day, respectively), reported by Carvalho et al. (2005). In tropical grasses with vertical growth, the SER is an important characteristic due to its significant interference in pasture structure and balance of competition for light (SBRISSIA, 2004). 
Table 4. Phyllochron (days/leaf.tiller) of two clones of dwarf elephant grass during four grazing cycles.

\begin{tabular}{cccc}
\hline \multirow{2}{*}{ Grazing Cycle } & \multicolumn{2}{c}{ Dwarf elephant grass clones $^{(\mathbf{1})}$} & \multirow{2}{*}{ SEM $^{(2)}$} \\
\cline { 2 - 3 } & BRS KURUMI & CNPGL 00-1-3 & 0.3 \\
C1 (from 05/11/09 to 01/12/09) & $5.03^{\mathrm{Aa}}$ & $4.03^{\mathrm{BCa}}$ & 0.4 \\
C2 (from 01/12/09 to 29/12/09) & $4.64^{\mathrm{Aba}}$ & $5.49^{\mathrm{Aa}}$ & 0.2 \\
C3 (from 29/12/09 to 22/01/10) & $3.90^{\mathrm{Ba}}$ & $4.08^{\mathrm{Ca}}$ & 0.1 \\
C4 (from 22/01/10 to 16/02/10) & $6.18^{\mathrm{Aa}}$ & $4.85^{\mathrm{ABb}}$ & 0.1 \\
\hline
\end{tabular}

(1) Means followed by the same lowercase letter on the line and by the same capital letter in the column do not differ $(\mathrm{P}<0.05)$ by "t" test of "Student" ("PDIFF"). (2) Standard error of the mean.

Table 5. Stem elongation rate (cm/tiller.day) of basal and aerial tillers of two clones of dwarf elephant grass during four grazing cycles.

\begin{tabular}{|c|c|c|c|c|c|}
\hline \multirow{3}{*}{ Grazing Cycle } & \multicolumn{4}{|c|}{ Dwarf elephant grass clones $^{(1)}$} & \multirow{3}{*}{$\mathbf{S E M}^{(2)}$} \\
\hline & \multicolumn{2}{|c|}{ BRS KURUMI } & \multicolumn{2}{|c|}{ CNPGL 00-1-3 } & \\
\hline & Basal Tillers & Aerial Tillers & Basal Tillers & Aerial Tillers & \\
\hline C1 (from $05 / 11 / 09$ to $01 / 12 / 09$ ) & $0.34^{\mathrm{AaX}}$ & $0.15^{\mathrm{AaXY}}$ & $0.42^{\mathrm{AaX}}$ & $0.21^{\mathrm{AaX}}$ & 0.07 \\
\hline C2 (from $01 / 12 / 09$ to $29 / 12 / 09$ ) & $0.48^{\mathrm{AaX}}$ & $0.22^{\mathrm{BaX}}$ & $0.55^{\operatorname{Aax}}$ & $0.17^{\mathrm{BaX}}$ & 0.08 \\
\hline C3 (from $29 / 12 / 09$ to $22 / 01 / 10$ ) & $0.51^{\mathrm{AaX}}$ & $0.16^{\mathrm{BaXY}}$ & $0.28^{\mathrm{AbY}}$ & $0.14^{\mathrm{AaY}}$ & 0.05 \\
\hline $\mathrm{C} 4$ (from $22 / 01 / 10$ to $16 / 02 / 10$ ) & $0.18^{\mathrm{AbY}}$ & $0.13^{\mathrm{AbY}}$ & $0.31^{\mathrm{AaX}}$ & $0.13^{\mathrm{BbY}}$ & 0.02 \\
\hline
\end{tabular}

(1) $\mathrm{A}>\mathrm{B}$ compares class of tillers within the combination clone/grazing cycles; $\mathrm{a}>\mathrm{b}$ compares clones in combination class of tillers/ grazing cycles; $\mathrm{X}>\mathrm{Y}$ compares grazing cycles within the combination clone/class tiller by " $\mathrm{t}$ " test of "Student" ("PDIFF"). (2) Standard error of the mean.

Leaf senescence rates (LSRs) were influenced by the interaction between clones, tiller class and grazing cycles $(\mathrm{P}=0.0415)$. Regarding tiller class, the BRS KURUMI clone had a greater value for basal tillers only in the fourth grazing cycle (1.12 $\mathrm{cm} /$ tiller.day). The CNPGL 00-1-3 clone, presented a greater value for basal tillers in the third cycle (0.69 cm/tiller.day) (Table 6). Comparatively, basal tillers had similar values in the first and fourth cycles. In the second grazing cycle, a greater basal tiller value was observed for clone BRS KURUMI $(1.40 \mathrm{~cm} /$ tiller.day), while in the third grazing cycle, clone CNPGL 00-1-3 had a greater value $(0.69 \mathrm{~cm} /$ tiller.day) (Table 6). Aerial tillers differed between clones only in the third grazing cycle, with a greater value for clone BRS KURUMI $(0.55 \mathrm{~cm} /$ tiller.day) (Table 6). Regarding the grazing cycle, cycle four presented a significant increase in leaf senescence of basal tillers for clone BRS KURUMI (Table 6), which is an interesting result since these tillers are cut more often than the basal ones (Table 5). It is likely that basal tillers of the CNPGL 00-1-3 clone were cut in cycle three (Table 5), which may have resulted in tiller renewal, as recovery of basal tillers was observed (Table 5), despite a high senescence rate (Table 6). Variation of the behavior of this variable during the experimental period determined the occurrence of the observed interaction. Hodgson (1990) proposes that leaf senescence is a natural process that characterizes the last phase of the development of leaves. The values observed for the studied clones are smaller than those reported by Paciullo et al. (2003) for elephant grass cv. Napier in different seasons $(0.9$ and $1.3 \mathrm{~cm} /$ tiller.day for aerial and basal tillers, respectively), demonstrating the potential use of the assessed clones. 
Table 6. Leaf senescence rate (cm/tiller.day) of basal and aerial tillers of two clones of dwarf elephant grass during four grazing cycles.

\begin{tabular}{cccccc}
\hline \multirow{2}{*}{ Grazing Cycle } & \multicolumn{3}{c}{ Dwarf elephant grass clones ${ }^{(\mathbf{1})}$} & \multirow{2}{*}{ SEM $^{(2)}$} \\
\cline { 2 - 4 } & \multicolumn{2}{c}{ BRS KURUMI } & CNPGL 00-1-3 & \\
\cline { 2 - 4 } & Basal Tillers & Aerial Tillers & Basal Tillers & Aerial Tillers & \\
\hline C1 (from 05/11/09 to 01/12/09) & $1.73^{\mathrm{AaX}}$ & $0.67^{\mathrm{AaX}}$ & $1.70^{\mathrm{AaX}}$ & $0.99^{\mathrm{AaX}}$ & 0.5 \\
C2 (from 01/12/09 to 29/12/09) & $1.40^{\mathrm{AaX}}$ & $0.65^{\mathrm{AaX}}$ & $0.19^{\mathrm{AbY}}$ & $0.14^{\mathrm{AaY}}$ & 0.2 \\
C3 (from 29/12/09 to 22/01/10) & $0.41^{\mathrm{AbY}}$ & $0.55^{\mathrm{AaX}}$ & $0.69^{\mathrm{AaX}}$ & $0.15^{\mathrm{BbY}}$ & 0.06 \\
C4 (from 22/01/10 to 16/02/10) & $1.12^{\mathrm{AaX}}$ & $0.30^{\mathrm{BaY}}$ & $0.61^{\mathrm{AaX}}$ & $0.27^{\mathrm{AaXY}}$ & 0.1 \\
\hline
\end{tabular}

(1) $\mathrm{A}>\mathrm{B}$ compares class of tillers within the combination clone/grazing cycles; a $>$ b compares clones in combination class of tillers/ grazing cycles; $\mathrm{X}>\mathrm{Y}$ compares grazing cycles within the combination clone/class tiller by "t" test of "Student" ("PDIFF"). (2) Standard error of the mean.

Leaf blade longevity was only influenced by the grazing cycles $(\mathrm{P}=0.0005)$. Leaf blade longevity increased with the advance of grazing cycles (Table 7) and was longer in cycle four, when rainfall sharply decreased (Figure 1). The hydric deficit may have been a temporary condition of low soil nutrient availability to plants due to the low availability of water to carry nutrients to the root system and their consequent absorption by the plant. As leaves compact their biomass to better use and preserve nutrients under reduced availability of growth factors, leaf longevity contributes to increase the mean time of permanence of nutrients in the plant (SBRISSIA, 2004).

Table 7. Leaf blade longevity (days) of clones of dwarf elephant grass during four grazing cycles.

\begin{tabular}{ccc}
\hline Grazing Cycle & Mean $^{(\mathbf{1})}$ & SEM $^{(2)}$ \\
\hline C1 (from 05/11/09 to 01/12/09) & $27.6^{\mathrm{B}}$ & 1.6 \\
C2 (from 01/12/09 to 29/12/09) & $31.3^{\mathrm{B}}$ & 1.7 \\
C3 (from 29/12/09 to 22/01/10) & $28.7^{\mathrm{B}}$ & 1.6 \\
C4 (from 22/01/10 to 16/02/10) & $37.1^{\mathrm{A}}$ & 0.5 \\
\hline
\end{tabular}

${ }^{(1)}$ Means in the same column followed by the same letter do not differ $(\mathrm{P}<0.05)$ by " $\mathrm{t}$ " test of "Student" ("PDIFF"). (2) Standard error of the mean.

The total number of leaves (TNL) was influenced by the interaction between grazing cycle and clones $(\mathrm{P}=0.0160)$ and by tiller class $(\mathrm{P}=0.0044)$. Basal tillers had higher TNL values (9.3 leaves/day) than aerial tillers (7.1 leaves/day). Likewise, Carvalho et al. (2005) and Paciullo et al. (2003) reported greater TNL for basal tillers (5.8 and 5.7 leaves/ tiller, respectively) in elephant grass cv. Napier. However, the values found for basal and aerial tillers of the studied clones were greater than those previously reported. Differences were observed between clones only in the first and second cycles, with greater TNL values in the first and second cycles for clones CNPGL 00-1-3 (8.9 leaves/tiller) and BRS KURUMI (8.2 leaves/tiller), respectively. Relative to grazing cycles, the TNL was smaller in the first and fourth cycles for clone BRS KURUMI and in the second cycle for clone CNPGL 00-1-3, demonstrating the observed interaction (Table 8). 
Table 8. Total number of leaves (leaves/tiller) of two clones of dwarf elephant grass during four grazing cycles.

\begin{tabular}{cccc}
\hline \multirow{2}{*}{ Grazing Cycle } & \multicolumn{2}{c}{ Dwarf elephant grass clones $^{(\mathbf{1})}$} & \multirow{2}{*}{ SEM $^{(2)}$} \\
\cline { 2 - 3 } & BRS KURUMI & CNPGL 00-1-3 & \\
\hline C1 (from 05/11/09 to 01/12/09) & $7.9^{\mathrm{Bb}}$ & $8.9^{\mathrm{Aa}}$ & 0.2 \\
C2 (from 01/12/09 to 29/12/09) & $8.2^{\mathrm{ABa}}$ & $7.1^{\mathrm{Bb}}$ & 0.3 \\
C3 (from 29/12/09 to 22/01/10) & $8.9^{\mathrm{Aa}}$ & $8.1^{\mathrm{Aa}}$ & 0.5 \\
C4 (from 22/01/10 to 16/02/10) & $7.9^{\mathrm{Ba}}$ & $8.5^{\mathrm{Aa}}$ & 0.4 \\
\hline
\end{tabular}

(1) Means followed by the same lowercase letter on the line and by the same capital letter in the column do not differ (P $<0.05)$ by "t" test of "Student" ("PDIFF"). (2) Standard error of the mean.

The number of live leaves (NLL) was influenced by the interaction among clones, tiller class and grazing cycle $(\mathrm{P}=0.0309)$. The clones presented similar NLL, with the exception of basal tillers in the fourth cycle and aerial tillers in the first cycle, when the highest values were observed for the CNPGL 00-1-3 clone (Table 9). For BRS Kurumi, greater NLL values were observed in basal tillers than those verified for aerial tillers, with exception in the second cycle, when the values between tiller class did not vary. For CNPGL 00-1-3, the NLL was greater in the basal tiller on the second and fourth cycles and did not vary with the tiller class in the first and third grazing cycles. The NLL was greater in the third cycle for the combination BRS Kurumi $\mathrm{x}$ basal tiller. For the combination BRS Kurumi $\mathrm{x}$ aerial tiller, the NLL value was greater in the third cycle compared to the first cycle. For the combination CNPGL 00-1-3 x basal tiller, the NLL observed in the fourth cycle was greater than the second and third cycles. The lowest value of NLL for the combination CNPGL 00-1-3 $\mathrm{x}$ aerial tiller was observed in the second cycle.

Table 9. Number of live leaves (leaves/tiller) of basal and aerial tillers of two clones of elephant grass during four grazing cycles.

\begin{tabular}{cccccc}
\hline \multirow{2}{*}{ Grazing Cycle } & \multicolumn{3}{c}{ Dwarf elephant grass clones ${ }^{(1)}$} \\
\cline { 2 - 4 } & \multicolumn{2}{c}{ BRS KURUMI } & CNPGL 00-1-3 & \multirow{2}{*}{ SEM $^{(2)}$} \\
\cline { 2 - 4 } & Basal Tillers & Aerial Tillers & Basal Tillers & Aerial Tillers & \\
\hline C1 (from 05/11/09 to 01/12/09) & $7.4^{\mathrm{AaY}}$ & $4.6^{\mathrm{BbY}}$ & $6.7^{\mathrm{AaXY}}$ & $6.8^{\mathrm{AaX}}$ & 0.5 \\
C2 (from 01/12/09 to 29/12/09) & $7.1^{\mathrm{AaY}}$ & $5.6^{\mathrm{AaXY}}$ & $7.9^{\mathrm{AaY}}$ & $5.0^{\mathrm{BaY}}$ & 0.6 \\
C3 (from 29/12/09 to 22/01/10) & $9.0^{\mathrm{AaX}}$ & $6.1^{\mathrm{BaX}}$ & $7.7^{\mathrm{AaY}}$ & $6.9^{\mathrm{AaX}}$ & 0.9 \\
C4 (from 22/01/10 to 16/02/10) & $7.3^{\mathrm{AbY}}$ & $5.7^{\mathrm{BaXY}}$ & $9.0^{\mathrm{AaX}}$ & $6.0^{\mathrm{BaX}}$ & 0.5 \\
\hline
\end{tabular}

(1) A > B compares class of tillers within the combination clone/grazing cycles; a $>$ b compares clones in combination class of tillers/ grazing cycles; $\mathrm{X}>\mathrm{Y}$ compares grazing cycles within the combination clone/class tiller by "te" test of "Student" ("PDIFF"). (2) Standard error of the mean.

The variation of the behavior of this variable during the experimental period determined the occurrence of the observed interaction. Although this characteristic is genetically controlled, variations in the availability of environmental growth factors caused by season variations and structural canopy modifications may interfere, even to a small degree, in the expression of morphogenetic variables through phenotypic plasticity (CARVALHO et al., 2005). In the present study, in addition to the contribution of the number of live leaves to quick and vigorous recovery, the handling system used (rotational stocking) is worth mentioning, as the defoliation interval allows restoration of the leaf area rate and the root system, contributing to greater soil coverage and competition against invading plants. 
The final leaf blade length (FLBL) was influenced by the interaction between tiller class and grazing cycle $(\mathrm{P}=0.0057)$. This interaction probably rose from the increase in basal tiller values from the second to the third cycles (although not significant, $\mathrm{P}>0.05$ ), which was not observed for the aerial tillers (Table 10). Greater values were observed for basal tillers in all grazing cycles (Table 10) due to the existence of greater sheaths on these tillers in relation to the aerial tillers, which eventually resulted in greater length of leaf blades grown from them (SILVA et al., 2008).

Table 10. Final leaf blade length $(\mathrm{cm})$ of basal and aerial tillers of two clones of dwarf elephant grass during four grazing cycles.

\begin{tabular}{cccc}
\hline \multirow{2}{*}{ Grazing Cycle } & \multicolumn{2}{c}{ Tiller class $^{(\mathbf{1})}$} & \multirow{2}{*}{ SEM $^{(2)}$} \\
\cline { 2 - 3 } & Basal & Aerial & 3.1 \\
C1 (from 05/11/09 to 01/12/09) & $44.6^{\mathrm{Aa}}$ & $25.9^{\mathrm{Ab}}$ & 2.4 \\
C2 (from 01/12/09 to 29/12/09) & $31.1^{\mathrm{Ba}}$ & $19.4^{\mathrm{Bb}}$ & 2.4 \\
C3 (from 29/12/09 to 22/01/10) & $32.2^{\mathrm{Ba}}$ & $19.1^{\mathrm{Bb}}$ & 1.7 \\
C4 (from 22/01/10 to 16/02/10) & $26.1^{\mathrm{Ca}}$ & $15.5^{\mathrm{Cb}}$ \\
\hline
\end{tabular}

(1) Means followed by the same lowercase letter on the line and by the same capital letter in the column do not differ $(\mathrm{P}<0.05)$ by "t" test of "Student" ("PDIFF"). (2) Standard error of the mean.

The FLBL of both basal and aerial tillers decreased with the progress of grazing cycles (Table 10). A similar behavior was observed by Madeiro et al. (2010) for basal tillers for the same clones of this study; this decrease is explained by the strong influence of climate conditions, which is corroborated by the results of the present study, as the greatest decrease occurred in the fourth cycle, when rainfall sharply decreased (Figure 1), thus limiting leaf blade growth. The decrease in FLBL indicates the influence of environmental variables and/or handling, which determine pasture structure and animal grazing activity. This phenomenon, called phenotypic plasticity, plays an important role in the plant-animal interface in pasture production systems because it makes forages more tolerant to grazing (LEMAIRE, 1997).

Basal tiller density (BTD) and aerial tiller density (ATD) were influenced by tiller class and grazing cycle interactions $(\mathrm{P}<0.0001)$. During the experimental period, ATD was greater than BTD (Table 11). In general, the number of basal tillers increased over the grazing cycles, especially between the first and fourth cycles, which presented an increase of over $62 \%$ in basal tillers. It is interesting to notice that while the BTD of cultivar Napier, which has normal size, decreases over grazing cycles due to death caused by cutting (CARVALHO et al., 2006b), the tiller density of the small-size clones investigated here increased, probably due to their smaller size and greater incidence of photosynthesis active radiation at the canopy base and the ensuing stimulation of basal gems. An increase in aerial tillers was observed over the grazing cycles, particularly up to the fourth cycle, when the mean tiller density was $167 \%$ greater than that of the first cycle.

The most significant increase in the number of aerial tillers with advancing grazing cycles may have been due to the progressive cutting of basal tillers during the experiment period, which may have stimulated the formation of aerial tillers (CARVALHO et al., 2006b). As observed for normal-size elephant grass cultivars, the participation of this tiller class in pasture forage production increases with the succession of grazing cycles (PACIULLO et al., 2003; CARVALHO et al., 2006b). The intensification of aerial tiller formation becomes even more important when the structure and nutritional values of the pasture are taken into account, as younger tillers generally have a greater leaf/stem ratio than basal tillers. 
Table 11. Population density of basal and aerial tillers (tillers $/ \mathrm{m}^{2}$ ) of two clones of dwarf elephant grass during six grazing cycles.

\begin{tabular}{cccc}
\hline \multirow{2}{*}{ Grazing Cycle } & \multicolumn{2}{c}{ Tiller class $^{(1)}$} & \multirow{2}{*}{ SEM $^{(2)}$} \\
\cline { 2 - 3 } & Basal & Aerial & 6.5 \\
C1 (from 05/11/09 to 01/12/09) & $36.8 \mathrm{Bb}$ & $73.1 \mathrm{Da}$ & 12.9 \\
C2 (from 01/12/09 to 29/12/09) & $49.1 \mathrm{ABb}$ & $100.6 \mathrm{CDa}$ & 7.3 \\
C3 (from 29/12/09 to 22/01/10) & $50.1 \mathrm{Ab}$ & $147.6 \mathrm{Ba}$ & 14.6 \\
C4 (from 22/01/10 to 16/02/10) & $59.8 \mathrm{Ab}$ & $195.6 \mathrm{Aa}$ & 19.6 \\
C5(from 16/02/10 to 12/03/10) & $47.6 \mathrm{ABb}$ & $136.0 \mathrm{ABCa}$ & 0.1 \\
C6 (from 12/03/10 to 06/04/10) & $13.1 \mathrm{Cb}$ & $19.1 \mathrm{Ea}$ & \\
\hline
\end{tabular}

(1) Means followed by the same lowercase letter on the line and by the same capital letter in the column do not differ (P $<0.05)$ by "t" test of "Student" ("PDIFF"). (2) Standard error of the mean.

The morphogenetic and structural characteristics of clones of dwarf elephant grass present variations determined by environmental conditions and structural pasture. The high leaf elongation rates combined with high leaf appearance rates indicate the potential of high production dry matter of leaves and restoration of the leaf area after grazing. The low height of clones of dwarf elephant grass provides increased densities of basal and aerial tillers during the grazing season of spring and summer, with higher participation of aerial tillers in the plant population.

\section{References}

ALMEIDA,E.X.; MARASCHIN, G.E.;HARTHMANN, O. E. L.; RIBEIRO FILHO, H. M. N.; SETELICH, E. A. Oferta de forragem de capim-elefante anão Mott e o rendimento animal. Revista Brasileira de Zootecnia, Viçosa, MG, v. 29, n. 5, p. 1288-1295, 2000.

BIRCHAM, J. S.; HODGSON, J. The influence of sward conditions on rates of herbage growth and senescence in mixed swards under continuous grazing management. Grass and Forage Science, v. 38, n. 4, p. 323-331, 1983.

CARVALHO, C. A. B.; DERESZ, F.; ROSSIELlO, R. O. P.; PACIULLO, D. S. C. Influência de intervalos de desfolha e de alturas do resíduo pós-pastejo sobre a produção e a composição da forragem e do leite em pastagens de capim-elefante. Boletim da Indústria Animal, Nova Odessa, v. 62, n. 3, p. 177-188, 2006 a.

CARVAlHO, C. A. B.; PACIUllo, D. S. C.; ROSSIELlO, R. O. P.; DERESZ, F. Dinâmica do perfilhamento em capim-elefante sob influência da altura do resíduo pós-pastejo. Pesquisa Agropecuária Brasileira, Brasília, v. 41, n. 1, p. 145-152, 2006b.

. Morfogênese do capim-elefante manejado sob duas alturas de resíduo pós-pastejo. Boletim da Indústria Animal, Nova Odessa, v. 62, n. 2, p. 101-109, 2005.

CARVALHO, P. C. F.; TRINDADE, J. K.; POLI, C. H. E. C.; NABINGER, C.; GENRO, T. C. M.; GONDA, H. L. Do bocado ao pastoreio de precisão: compreendendo a interface planta animal para explorar a multi-funcionalidade das pastagens. Revista Brasileira de Zootecnia, Viçosa, MG, v. 38, p. 109-122, 2009 Suplemento Especial.

CHAPMAN, D. F.; LEMAIRE, G. Morphogenetic and structural determinants of regrowth after defoliation. In: INTERNATIONAL GRASSLAND CONGRESS, 17., 1993, New Zealand. Proceedings... New Zealand: [s. n.], 1993. p. 95-104.

COLLINS, R. P.; JONES, M. B. The effects of temperature on leaf growth in Cyperus longus, a temperate $\mathrm{C}_{4}$ species. Annals of Botany, Oxford, v. 61, n. 3, p. 355-362, 1988.

CRUZ, P.; BOVAL, M. Effect of nitrogen on some morphogenetic traits of temperate and tropical perennial forage. In: LEMAIRE, G.; HODGSON, J.; MORAES, A. (Ed.). Grassland Ecophysiology and grazing ecology. Wallingford, UK: CABI International, 2000. p. 151-168.

DAVIES, A. Leaf tissue remaining after cutting and regrowth in perennial ryegrass. The Journal of Agriculture Science, Cambridge, v. 82, n. 1, p. 165-172, 1974.

DURU, M.; DUCROCQ, H. Growth and senescence of successive leaves on a Cooksfoot tiller. Effect of nitrogen and cutting regime. Annals of Botany, Oxford, v. 85, n. 5 , p. $645-653,2000$.

EMPRESA BRASILEIRA DE PESQUISA AGROPECUÁRIA - EMBRAPA. Centro Nacional de 
Pesquisa de Solos. Sistema brasileiro de classificação de solos. 2. ed. Rio de Janeiro: Embrapa, 2006. 306 p.

GOMIDE, C. A. M.; GOMIDE, J. A. Morfogênese de cultivares de Panicum maximum Jacq. Revista Brasileira de Zootecnia, Viçosa, MG, v. 29, n. 2, p. 341-348, 2000.

GOMIDE, C. A. M.; PACIULlO, D. S. C.; COSTA, I. A.; SOUZA, B. P.; PEREIRA, A. V.; MARTINS, C. E. Produção de forragem e estrutura do dossel em dois clones de capim-elefante anão sob diferentes manejos. In: REUNIÃO DA SOCIEDADE BRASILEIRA DE ZOOTECNIA, 45., 2008, Lavras. Anais... Lavras: SBZ/ UFLA, 2008. CD-ROM.

HODGSON, J. Grazing management: science into practice. London: Longman Scientific and Technical, Longman Group, 1990. 203 p.

LAWLOR, D. W. Photosynthesis, productivity and environment. Journal Experimental Botany, Oxford, v. 46, Especial Issue, p. 1449-1461, 1995.

LEMAIRE, E.; CHAPMAN, D. Tissue flows in grazed plant comunities. In:. HODGSON, I.; ILLIUS, A. W. (Ed.). The ecology and management of grazing systems. London: CAB International, 1996. p. 3-36.

LEMAIRE, G. The physiology of grass growth under grazing: tissue turnover. In: SIMPÓSIO INTERNACIONAL SOBRE PRODUÇÃO ANIMAL EM PASTEJO, 1997, Viçosa. Anais... Viçosa, MG: Universidade Federal de Viçosa, 1997. p. 115-144.

MADEIRO, A. S.; PACIULLO, D. S. C.; MORENZ, M. J. F.; GOMIDE, C. A. M.; LEDO, F. J. S. Características morfogênicas e estruturais de perfilhos basais de clones de capim-elefante manejados sob lotação rotacionada. In: REUNIÃO ANUAL DA SOCIEDADE BRASILEIRA DE ZOOTECNIA, 47., 2010, Salvador. Anais... Salvador: SBZ, 2010. CD-ROM.

NABINGER, C.; PONTES, L. S. Morfogênese de plantas forrageiras e estrutura do pasto. In: REUNIÃO ANUAL DA SOCIEDADE BRASILEIRA DE ZOOTECNIA, 2001, Piracicaba. Anais... Piracicaba: Fundação de Estudos Agrários Luiz de Queiroz, 2001. p. 755-770.

PACIULLO, D. S. C.; DERESZ, F.; AROEIRA, L. J. M.; MORENZ, M. J. F.; VERNEQUE, R. S. Morfogênese e acúmulo de biomassa foliar em pastagem de capimelefante avaliada em diferentes épocas do ano. Pesquisa Agropecuária Brasileira, Brasília, v. 38, n. 7, p. 881-887, 2003.
PEREIRA, A. V.; LÉDO, F. J. S. Melhoramento genético de Pennisetum purpureum. In: RESENDE, R. M. S.; VALLE, C. B.; JANK, L. (Ed.). Melhoramento de forrageiras tropicais. Campo Grande: Embrapa Gado de Corte, 2008. p. 89-116.

PINTO, J. C.; GOMIDE, J. A.; MAESTRI, M.; LOPES, N. F. Crescimento de folhas de gramíneas forrageiras tropicais cultivadas em vasos, com duas doses de nitrogênio. Revista Brasileira de Zootecnia, Viçosa, MG, v. 23, n. 3, p. 327-332, 1994.

RODRIGUES, C. S.; NASCIMENTO JÚNIOR, D.; SILVA, S. C. da; SILVEIRA, M. C. T.; SOUSA, B. M. L.; DETMANN, E. Characterization of tropical forage grass development pattern through the morphogenetic and structural characteristics. Revista Brasileira de Zootecnia, Viçosa, MG, v. 40, n. 3, p. 527-534, 2011.

SBRISSIA,A. F. Morfogênese, dinâmica do perfilhamento e do acúmulo de forragem em pastos de capim-Marandu sob lotação contínua. 2004. Tese (Doutorado em Agronomia) - Escola Superior de Agricultura Luiz de Queiroz, Universidade de São Paulo, Piracicaba.

SILVA, S. C. da; NASCIMENTO JÚNIOR, D. do; SBRISSIA, A. F.; PEREIRA, L. E. T. Dinâmica de população de plantas forrageiras em pastagens. In: SIMPÓSIO SOBRE MANEJO ESTRATÉGICO DA PASTAGEM, 4., 2008, Viçosa, MG. Anais... Viçosa, MG: Suprema Gráfica e Editora Ltda., 2008. v. 1, p. 75100.

SKINNER, R. H.; NELSON, C. J. Role of leaf appearance rate and production and site usage during tall fescue canopy development. Annals of Botany, Oxford, v. 70, n. 6, p. 493-499, 1992.

VAN ESBROECK, G. A.; HUSSEY, M. A.; SANDERSON, M. A. Leaf appearance rate and final leaf number of Switch grass cultivars. Crop Science, Madison, v. 37, n. 2, p. 864-870, 1997.

VINE, D. A. Sward structure changes within a perennial ryegrass sward: leaf appearance and desth. Grass and Forage Science, London, v. 38, n. 4, p. 231-242, 1983.

WOLFINGER, R. D. Covariance structure selection in general mixed models. Communications in Statistics Simulation and Computation, Philadelphia, v. 22, n. 4, p. 1079-1106, 1993. 